\title{
Influence of Organic Fertilizers on Onion Quality
}

\author{
Bojana Petrovic*, Robert Pokluda \\ Department of Vegetable Sciences and Floriculture, Mendel University in Brno, Lednice, Czech Republic
}

Received: 28 August 2018

Accepted: 21 November 2018

\begin{abstract}
This paper describes the influence of organic fertilizers on the content of vitamin $\mathrm{C}$, carotenoids, antioxidants and heavy metals $(\mathrm{Cd}, \mathrm{Cu}, \mathrm{Pb})$ in two onion cultivars, i.e., "Stuttgarter Riesen" and "Rote Laaer". The experiment was done during 2016 and 2017. Treatments B-Stimul (contains Azospirillum, Azotobacter, Bacillus, Chlorella vulgaris and Herbaspirillum), Ekobooster 2 (contains organic matter and NPK stimulates) and Vermifit A (composition nutrients in immediately acceptable forms, plant hormones, enzymes, extract of compost of californian earthworm) were used. The results showed that the cultivar "Stuttgarter Riesen"at the treatment B-stimul in 2016 reached the highest content of vitamin C (35.4 mg kg-1 and carotenoids (14.6 mg kg-1), while in 2017 the highest content of vitamin

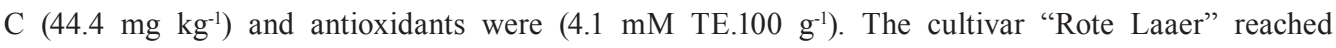
the highest content of carotenoids in both years in the treatment Ekobooster 2, $7.5 \mathrm{mg} \mathrm{kg}^{-1}$ (2016) and $22.8 \mathrm{mg} \mathrm{kg}^{-1}$ (2017). In 2016, control showed the highest content of vitamin $\mathrm{C}\left(17.5 \mathrm{mg} \mathrm{kg}^{-1}\right)$ and antioxidants (18.5 mM TE. $\left.100 \mathrm{~g}^{-1}\right)$. In both years and in both cultivars, the content of $\mathrm{Cd}$ and $\mathrm{Pb}$ was in line with European law, and the content of $\mathrm{Cu}$ was lower than those recommended by EU standards.
\end{abstract}

Keywords: vitamin C, carotenoids, antioxidants, heavy metals;, Allium cepa

\section{Introduction}

Onion (Allium cepa) is the most widely cultivated species of the genus Allium [1]. Many reports have indicated that onions have a wide range of beneficial properties for human health, such as polyphenols, flavonoids, and antioxidants [2] as well as carbohydrates and sugar [3]. The organic production system aims at supporting and sustaining healthy ecosystems, soil, farmers, food production, the community, and the economy [4]. Onion, being a bulbous vegetable, responds well to supplementation of organic manures, provided soil conditions are congenial. It is a common perception that the application of organic fertilizers is most beneficial to obtain better yield and quality onions. Organic fertilizers improved the chemical and physical properties of onion [5]. The most commonly used bioadditives are fertilizers based on organic matter combined with plant growth-promoting microorganisms (PGPM), arbuscular mycorrhizal fungi (AMF), biocontrol fungi (e.g., Trichoderma harzianum), and plant growth-promoting bacteria (PGPB; e.g., Azosprillum, Azotobacter, Pseudomonas) [6]. According to Fawzy et al. [7], the economic effect of liquid organic fertilizer on agriculture may be a factor in the extension of its practice in larger areas. Over the years, inorganic fertilizers have been widely used worldwide to support and optimize the growth of vegetables. However, the use of organic fertilizers has gained more importance globally in the last few decades due to efforts made for the conservation of agriculture [8]. The application of biofertilizers results in increased mineral and water 
uptake, root development, vegetative growth and nitrogen fixation, and also stimulates the production of growth-promoting substances like vitamin-B complex, indole acetic acid (IAA) and gibberellic acids, etc. [9]. In several studies, the effects of different organic fertilization on quality of onion were investigated. Olle and Williams [10] showed that the content of vitamin $\mathrm{C}$ in onion treated with different organic fertilizers (phytopellets standard, malzkeim pellets, organic tree fertilizer) was greater than in the unfertilized control onions, but there were no statistically significant differences between organic treatments. Hidangmayum and Sharma [11] concluded that using organic seaweed liquid extracts of Ascophyllum nodosum as a plant biostimulant on growth and yield of onion with a concentration of $0.55 \%$ showed the best influence of content on carotenoids $(0.61 \mathrm{mg} / \mathrm{g})$ compared to control, and liquid extracts with a concentration above and belowthis range. Similar results were reported by Devendra et al. [9], with biofertilizer that contains Azotobacter with a dose of $1.99 \mathrm{~g} / \mathrm{m}^{2}$ on the content of carotenoids in onion compared to control and the same biofertilizer with a concentration above and below this range. Feiyue et al. [12] also found that antioxidant activity was higher in organic onion, and the flavonols in organic onion were up to $20 \%$ higher compared to conventional. Proper fertility has a big influence on the quality of vegetables. The excessive application of nitrogen and other inorganic fertilizers and organic manures to vegetables can accumulate high levels of nitrate as well as heavy metals [13]. Sometimes, vegetable species may accumulate significant amounts of heavy metals, decreasing the quality and biological value of products without visible symptoms of their damage [14]. Therefore, the main objective of this investigation was to study the effect of different organic fertilizers on the internal qualities parameters of vitamin $\mathrm{C}$, carotenoids, antioxidants, and heavy metals $(\mathrm{Cd}, \mathrm{Cu}$, $\mathrm{Pb}$ ) in two different onion cultivars.

\section{Materials and Methods}

We used two onion cultivars from the Permal and Company in the Czech Republic: "Stuttgarter Riesen" and "Rote Laaer". The research was conducted in 2016 and 2017. Seeds were sown in both yearson 15 March, while transplanting on 4 May 2016 and 10 May 2017. The experiment took place in the experimental field of the Faculty of Horticulture in Lednice, Mendel University in Brno, Czech Republic (4847'36'N, $\left.16^{\circ} 47^{\prime} 48^{\prime \prime} \mathrm{E}\right)$. Each cultivar contained 16 plots with a size of $4 \mathrm{~m}^{2}(2 \mathrm{~m} \mathrm{x} 2 \mathrm{~m})$ per plot in 2016, while in 2017 the size of plots was $2 \times 1.8 \mathrm{~m}^{2}$. The spacing between plants was $0.3 \times 0.035 \mathrm{~m}$ in both years. Harvesting was done on 6 Augustin the first year and 12 August in the second year. A complete Latin square experimental design was used with 4 replications of each of four fertilization treatments:
1. B-stimul (Rawat, Czech Republic), contains Azospirillum, Azotobacter, Bacillus, Chlorella vulgaris and Herbaspirillum at a concentration of $107 \mathrm{cfu} / \mathrm{g}$.

2. Ekobooster 2 (Ekopatent, Serbia), contains organic matter $7.8 \%, \mathrm{~N}-9 \%, \mathrm{P}-1 \%, \mathrm{~K}-4 \%$.

3. Vermifit A (Primrose, Czech Republic),compost from california earthworms and peat, contains nutrients in immediately acceptable forms, plant hormones, enzymes, amino acids, and sugars. The composition is as follows: $\mathrm{N}-1.9 \%, \mathrm{~K}-35.6 \%, \mathrm{P}-2.8 \%$, dry matter $0.95 \%$.

4. Control (without fertilization).

According to fertilizer company instructions, the treatment Vermifit A was applied four times during the vegetation period while B-stimul and Ekobooster 2 were applied three times. In both years, treatments were applied after transplanting, Vermifit A was applied every 10 days, while, Ekobooster 2 and B-stimul were applied every 15 days. The application was foliar for each treatment with a dose for $1 \mathrm{~m}^{2}$ : B-stimul $3.38 \mathrm{~g}$ in 3.38 litof water, Ekobooster $20.125 \mathrm{ml}$ in $25 \mathrm{ml}$ of water,and Vermifit A $0.4 \mathrm{ml}$ in $39.6 \mathrm{ml}$ of water. The onion cultivars in both seasons were considered for determining the content of vitamin $\mathrm{C}$, carotenoids, antioxidants, and heavy metals $(\mathrm{Cd}, \mathrm{Cu}, \mathrm{Pb})$. Analyses for determining quality were done after harvest, at the laboratory of the Faculty of Horticulture. All bulbs for analyses were medium size, peeled and undamaged.

\section{Laboratory Analysis}

The determination of vitamin $\mathrm{C}$ was done by using HPLC method according to Arya et al. [15]. Chromatographic analyses were performed by HPLC (ECOM, ECB 2000 Praha, Czech Republic) at $254 \mathrm{~nm}$ using a Knauer detector. Analytical column, YMC-Triart C18 150 x 4.6 mm. D. S-5 $\mu 112 \mathrm{~nm}$. TA12SO5 1546WT, pre-column CGC 3x30 Separon SGX $18.7 \mathrm{~nm}$, isocratic mode of mobile phase (tetrabutylammonium hydroxide), oxalic acid, distilled water, 10:20:70. Determination of carotenoids was doneaccording to HOLM methodology [38] by using a microwave extraction system (Start E, Milestone, Germany). The absorbance was measured at the wavelength of $440 \mathrm{~nm}$ for carotenoids by spectrophotometer by Specord 50 PLUS, (Analytik Jena, Germany). The total antioxidant capacity was determined by DPPH method [16]. The measure was done at a wavelength of $515 \mathrm{~nm}$. The standard curve was prepared using a different concentration of Trolox. To determine cadmium, copper,and lead, 15 plants were used from each repetition. All bulbs were washed in deionized water, and the uniform white shafts were the material for analysis. The method used was flow-through stripping chronopotentiometry (Eca Flow, ISTRAN, SK) after mineralization of the sample with nitric acid. 


\section{Weather Conditions in Onion-Growing Season}

Mean monthly temperature, precipitation and sunshine duration was measured during the vegetation period (May-August). Mean monthly temperature during the vegetation period in 2016 and 2017 was 18.9 and $19.7^{\circ} \mathrm{C}$. In 2016 , the quantities of precipitation (mm) in May (52.6), July (114) and August (46.4) were higher compared to those months in 2017, in May (24.4), July (71.7) and August (23.7). The amount of sunshine was lower in 2016 compared to 2017. The biggest difference was in June, when in 2016 the average number of sunny hours was 253, while in the same month in 2017 it was 314.

\section{Statistical Analyses}

All data were evaluated by two-way analysis of variance (ANOVA) using PC software Statistica CZ v. 12 (Stat Soft). Vertical bars denote standard error. Differences in content levels among the varieties were estimated through Fisher's LSD test at $\mathrm{P}<0.05$.

\section{Results and Discussion}

\section{Soil Analysis}

Soil analysis showed $\mathrm{pH}\left(\mathrm{H}_{2} \mathrm{O}\right)$ of 7.2 in 2016 and 7.1 in 2017 at a depth of $0.3 \mathrm{~m}$. According to agrochemical analyses for 2016, the content of $\mathrm{N}$ was less than usually required onion. Because of that, on the field size of $128 \mathrm{~m}^{2} 6.4 \mathrm{~kg} \mathrm{~N}$ universal organic fertilizer 8-3-8 product from the company Rašelina, Czech Republic was added. Agrochemical analysis for 2017 showed that content of $\mathrm{N}$ in the soil was higher than usually required in onions.

\section{Vitamin C}

Vitamin C (L-ascorbic acid) is a water-soluble antioxidant that serves a predominantly protective role [17]. According to the World Health Organization,a daily amount of vitamin $\mathrm{C}$ should be $45-50 \mathrm{mg}$ [18]. The content of vitamin $\mathrm{C}$ was higher in both cultivars in 2017 compared to 2016. The vitamin C content in the cultivar "Stuttgarter Riesen" ranged from 15.9 to $35.4 \mathrm{mg} \mathrm{kg}^{-1}$ in 2016 and from 21.6 to $44.4 \mathrm{mg} \mathrm{kg}^{-1}$ in 2017 (Fig. 1a). Results showed that the highest content of vitamin C in the cultivar "Stuttgarter Riesen" in the treatment B-stimul in 2016 was $\left(35.4 \mathrm{mg} \mathrm{kg}^{-1}\right)$ as well as in 2017 (44.4 $\left.\mathrm{mg} \mathrm{kg}^{-1}\right)$. The treatment B-stimul in the cultivar "Stuttgarter Riesen" in 2016 showed 55.2\% higher content of vitamin C compared to control, and $51 \%$ compared to Ekobooster 2, 37.6\% compared to Vermifit A. The same treatment (B-stimul) in the cultivar "Stuttgarter Riesen" in 2017 showed 51.4\% higher content of vitamin C compared to Ekobooster 2 , and $24 \%$ compared to Vermifit A, while between the treatment B-stimul and control it was not significantly different.

The treatment B-stimul contains different bacteria and algae (Azospirillum, Azotobacter, Bacillus, Chlorella vulgaris and Herbaspirillum). Many researchers showed the positive effect of biofertilizers on the growth and quality of onion [19, 20, 21]. Dilpreet et al. [22] found the maximum content of vitamin $\mathrm{C}$ in treatment with farmyard manure mixed with Azotobacter. They concluded that microbial inoculants fix atmospheric nitrogen and growth-promoting substances that accelerate the physical process enhance the ascorbic acid content of onion with biofertilizer inoculation. In the cultivar "Rote Laaer" (Fig. 1b) in 2016, content of vitamin $\mathrm{C}$ ranged from 8.5 to $17.5 \mathrm{mg} \mathrm{kg}^{-1}$ and from 17.1 to $21.3 \mathrm{mg} \mathrm{kg}^{-1}$ in 2017. In 2016 the control showed the highest content of vitamin $\mathrm{C}\left(17.5 \mathrm{mg} \mathrm{kg}^{-1}\right)$, while in 2017 Vermifit Ashowed (21.3 mg kg-1). According to those results, it can be concluded that in both years
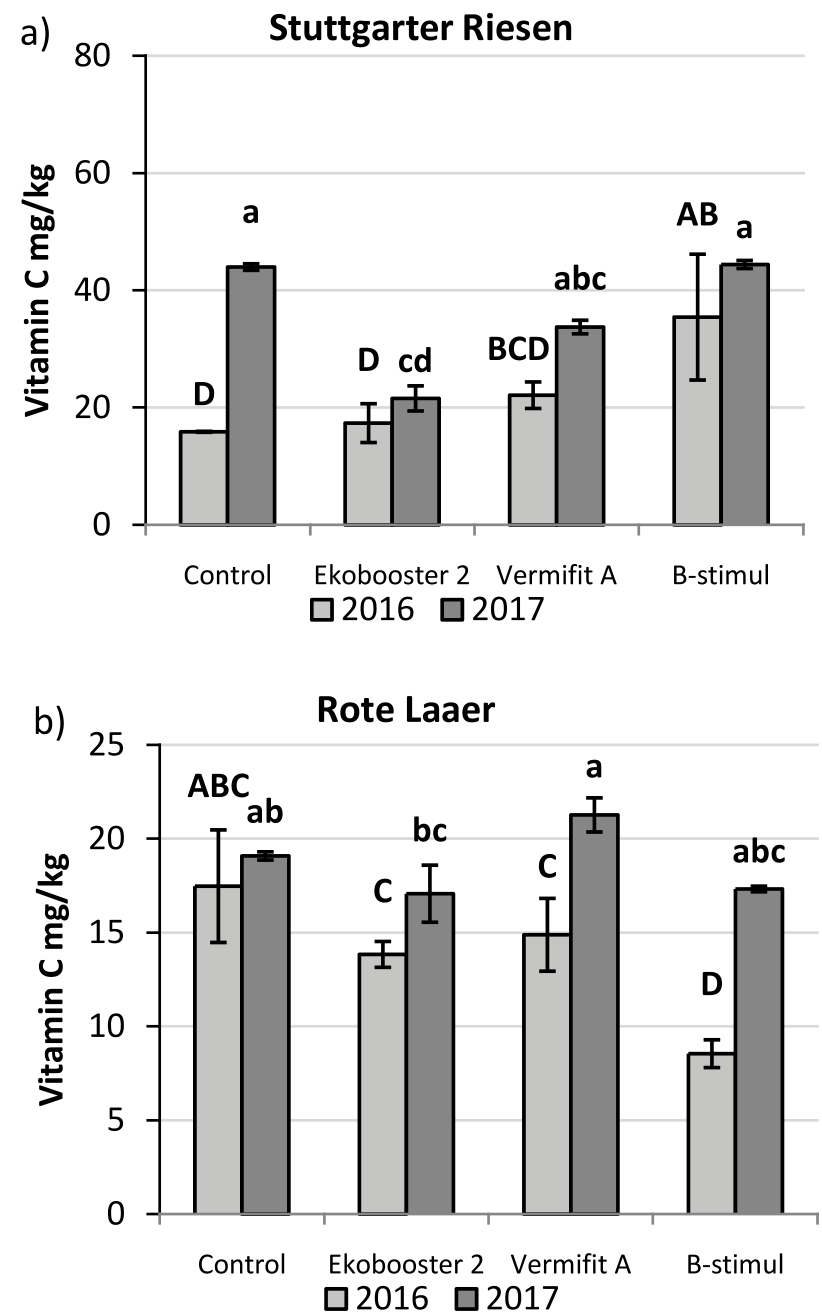

Fig. 1. Onion bulb content of vitamin C in the cultivar "Stuttgarter Riesen" a) and cultivar "Rote Laaer" b).

Capital letters indicate the statistical differences according to Fisher's LSD test at $\mathrm{P}<0.05$ between treatments and cultivars in 2016, and lowercase letters in 2017. Vertical bars show standard error. 
in both cultivars in all treatments including control content of vitamin $\mathrm{C}$ was not higher compared to USDA (2017), where the content of vitamin $\mathrm{C}$ in raw onion is $7.40 \mathrm{mg} / 100 \mathrm{~g}$ [37].

\section{Carotenoids}

The content of carotenoids in vegetables cannot be considered to be an absolute value, and it may be affected by several factors (the cultivar, climate, and growing conditions such as fertilizer application and plant nutrient availability). As a result of many functions or properties attributed to the production of carotenoids, there is a worldwide effort to obtain reliable analytical data that provides deeper insights into the development of these compounds [23]. In this research, the results showed the highest content of carotenoids in the cultivar "Stuttgarter Riesen" in 2016 in the treatment B-stimul (14.6 $\mathrm{mg} \mathrm{kg}^{-1}$ ), which was $72.7 \%$ higher compared to control, 80.1\% compared to Ekobooster 2, and 39.4\% compared to Vermifit A. (Fig. 2a).

In the same cultivar in 2017 Ekobooster 2 (24.2 $\mathrm{mg} \mathrm{kg}^{-1}$ ) showed the highest content of carotenoids. The treatment Ekobooster 2 reached $29.3 \%$ higher content of carotenoids compared to B-stimul and 55.7\% compared to control (Fig. 2a). The cultivar "Rote Laaer" (Fig. 2b) in 2016 at the treatment Ekobooster 2 showed the highest content of carotenoids $\left(7.5 \mathrm{mg} \mathrm{kg}^{-1}\right)$, as well as in $2017\left(22.8 \mathrm{mg} \mathrm{kg}^{-1}\right)$. Compared to other treatments, the content of carotenoids at the cultivar "Rote Laaer" at the treatment Ekobooster 2 in 2016 was higherby $25 \%$ compared to Vermifit A, $22.5 \%$ compared to B-stimul, and $38.6 \%$ compared to control, while in 2017 it was $74.7 \%$ compared to Vermifit A, $81.7 \%$ compared to B-stimul, and $15.7 \%$, compared to control. Genetic variability for total carotenoids among different Allium species has previously been reported [24]. The content of carotenoids in both cultivars was higher in 2017 compared to 2016. As mentioned above, the same results were obtained in determining vitamin C. The results of weather conditions showed that average sunshine duration was lower in 2016 compared to 2017. The biggest difference was in June, when in 2016 the average number of sunny hours was 253 , while in the same month in 2017 it was 314. In this study, at lower sunshine duration,the content of carotenoids and vitamin $\mathrm{C}$ in thev arieties "Stuttgarter Riesen" and "Rote Laaer" decreased. The significant decrease in the content of carotenoids and vitamin $\mathrm{C}$ in those cultivars under lower sunshine duration suggested that it could cause a considerable decrease in quality. Many researchers have reported that different weather conditions influence quality and yield of vegetables [25-27]. The treatment Ekobooster 2 showed the highest content of carotenoids in the cultivar "Rote Laaer" in both years, as well as in the cultivar "Stuttgarter Riesen"in 2017. The organic matter and content of NPK showed the positive effect on the content of carotenoids. Similar findings were reported by Zhang et al. [28], who found that content
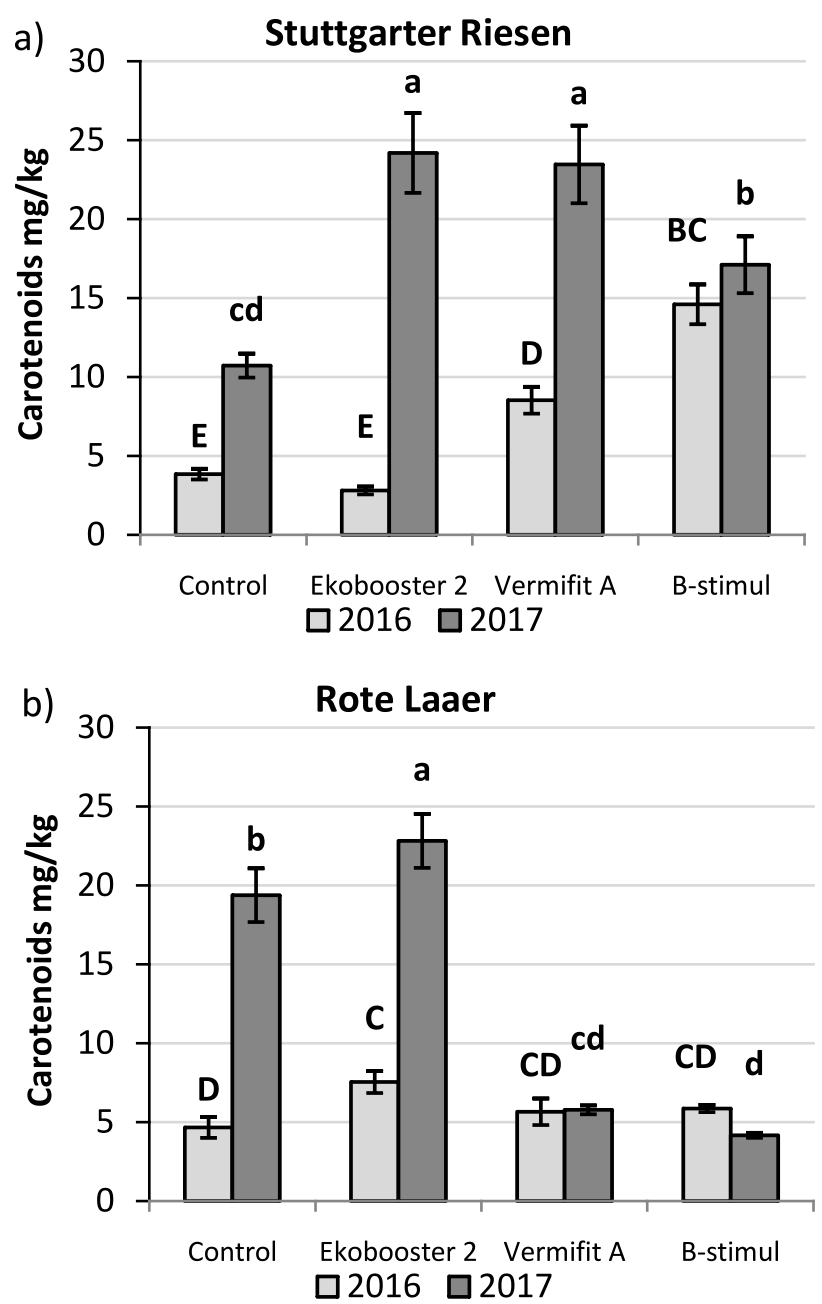

Fig. 2. Carotenoid content in onion bulbs in cultivar "Stuttgarter Riesen" a) and cultivar "Rote Laaer" b).

Capital letters indicate the statistical differences according to Fisher's LSD test at $\mathrm{P}<0.05$ between treatments and cultivars in 2016, and lowercase letters in 2017. Vertical bars show standard error.

of carotenoids was increased in organic fertilizer with $\mathrm{N}$. This can be attributed to the sufficient $\mathrm{N}$ uptake, enhanced onion plants to absorb more $\mathrm{N}$ and in turn to build more chlorophyll structure and carotenoids [29].

\section{Antioxidants}

According to many researchers [30] white, yellow and sweet, onion is a species consumed widely across the world and possesses a high content of flavonoid compounds (mainly quercetin and its conjugates) and sulfur compounds (i.e., thiosulphinates) - both of which have a high level of antioxidant activity. In the present study, the content of antioxidants in the cultivar "Stuttgarter Riesen" was higher in 2017 compared to 2016 , as in the case of the content of vitamin C and carotenoids. The highest content of antioxidants in the cultivar "Stuttgarter Riesen" in 2016 (Fig. 3a) was in the treatment Vermifit A $\left(2.8 \mathrm{mM}\right.$ TE.100 $\left.\mathrm{g}^{-1}\right)$, while in 2017 B-stimul (4.1 mM TE.100 $\left.\mathrm{g}^{-1}\right)$ showed the highest 
content of antioxidants.At the cultivar "Rote Laaer" in 2016, control (18.5 mM TE.100 $\left.\mathrm{g}^{-1}\right)$ showed the best effect as regardsthe content of antioxidants. The same cultivar (Rote Laaer) reached the highest content of antioxidants in 2017 at the treatment B-Stimul $(19.5 \mathrm{mM}$ TE.100 $\mathrm{g}^{-1}$ ) and it was significantly different compared to other treatments (Fig. 3b). The red onion (Rote Laaer) extracts showed good antioxidant activity in both years (2016-2017), varying from 7.3 to $19.5 \mathrm{mM}$ TE.100 $\mathrm{g}^{-1}$, and better than in the yellow cultivar (Stuttgarter Riesen) ranging from 1.9 to $4.1 \mathrm{mM}$ TE. $100 \mathrm{gg}^{-1}$ in 2016 and 2017. Kandoliya et al. [3] reported that the DPPH antioxidant activity for onion varied from 63.8 to $77.6 \%$ in red onion compared to white onion antioxidant activity ranging from 58.1 to $66.4 \%$. The higher content of antioxidants in red onion was reported by numerous investigators $[2,31]$. Most of the researchers have mentioned that high content of vitamin $\mathrm{C}$ and carotenoids lead to the high antioxidants activity. Nonetheless, the present study of yellow and red onion showed a negative relationship between results of those parameters. Although the cultivar "Stuttgarter Riesen"in 2017 showed higher
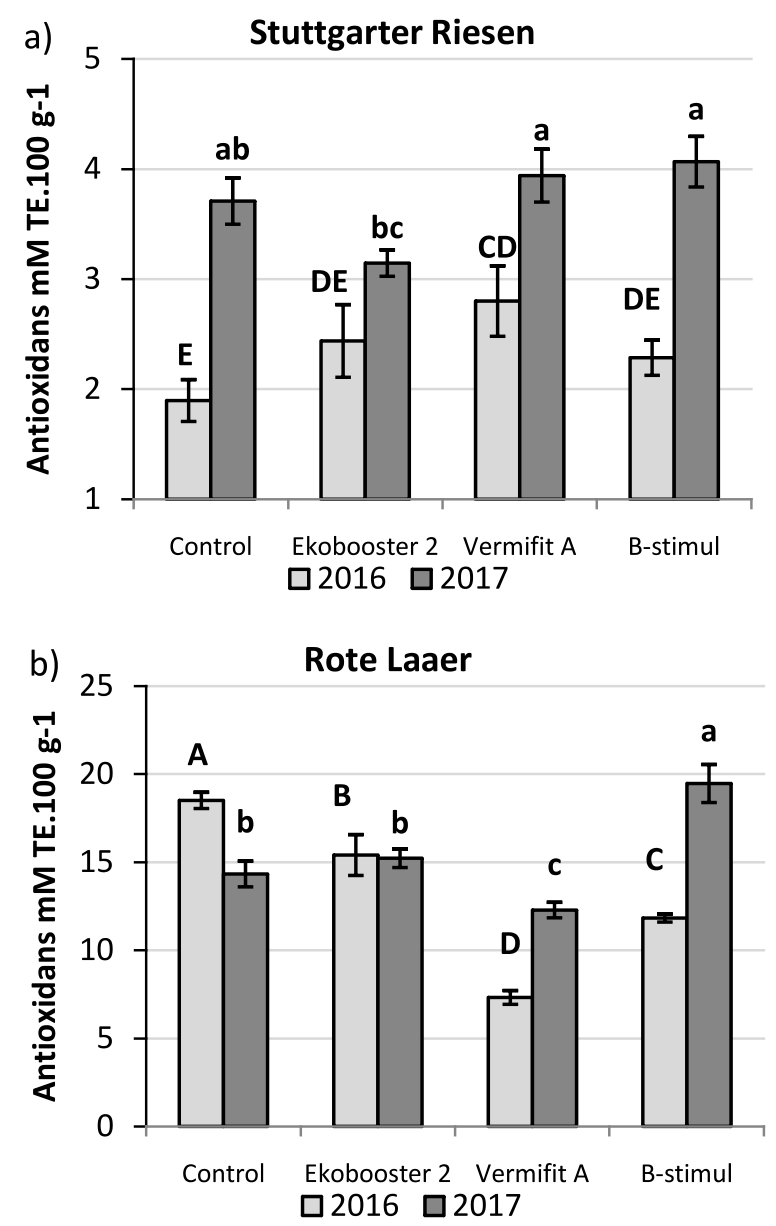

Fig. 3. Antioxidants in onion bulbs of the cultivar "Stuttgarter Riesen" a) and cultivar "Rote Laaer" b).

Capital letters indicate the statistical differences according to Fisher's LSD test at $\mathrm{P}<0.05$ between treatments and cultivars in 2016, and lowercase letters in 2017. Vertical bars show standard error. content of vitamin $\mathrm{C}$ and carotenoids in the treatments Ekobooster 2, Vermifit A, and B-stimul, the content of antioxidants in 2017 was lower compared to "Rote Laaer" (Fig. 3a, 3b).

\section{Heavy Metals}

Samples from two onion cultivars grown under different treatments were analyzed for determining heavy metals $(\mathrm{Cd}, \mathrm{Cu}, \mathrm{Pb})$. In the cultivar "Stuttgarter

Table 1. Heavy metals content at the cultivars "Stuttgarter Riesen"and "Rote Laaer" in 2016 and 2017 ( $\left.\mu \mathrm{g} \mathrm{kg}{ }^{-1} \mathrm{~F} . \mathrm{W}\right)$.

\begin{tabular}{|c|c|c|c|c|}
\hline \multicolumn{5}{|c|}{2016} \\
\hline Cultivar & Treatment & $\mathrm{Cd}$ & $\mathrm{Pb}$ & $\mathrm{Cu}$ \\
\hline $\begin{array}{c}\text { Stuttgarter } \\
\text { Riesen }\end{array}$ & B-stimul & $11.05 \mathrm{de}$ & $26.26 \mathrm{c}$ & $250.13 \mathrm{c}$ \\
\hline $\begin{array}{l}\text { Stuttgarter } \\
\text { Riesen }\end{array}$ & Control & $18.73 \mathrm{c}$ & $15 \mathrm{~d}$ & $128.55 \mathrm{~d}$ \\
\hline $\begin{array}{l}\text { Stuttgarter } \\
\text { Riesen }\end{array}$ & Ekobooster2 & $19.31 \mathrm{bc}$ & $14.55 \mathrm{~d}$ & $139.56 \mathrm{~d}$ \\
\hline $\begin{array}{l}\text { Stuttgarter } \\
\text { Riesen }\end{array}$ & VermiFit A & $18.81 \mathrm{c}$ & $35.46 \mathrm{~b}$ & $151.49 \mathrm{~d}$ \\
\hline & & 16.97 & 22.81 & 167.43 \\
\hline \multicolumn{5}{|c|}{2017} \\
\hline $\begin{array}{l}\text { Stuttgarter } \\
\text { Riesen }\end{array}$ & B-stimul & $7.34 \mathrm{e}$ & $49.76 \mathrm{a}$ & $787.96 \mathrm{a}$ \\
\hline $\begin{array}{l}\text { Stuttgarter } \\
\text { Riesen }\end{array}$ & Control & $31.95 \mathrm{a}$ & $55.74 \mathrm{a}$ & $512.72 \mathrm{~b}$ \\
\hline $\begin{array}{l}\text { Stuttgarter } \\
\text { Riesen }\end{array}$ & Ekobooster2 & $26.87 \mathrm{ab}$ & $57.48 \mathrm{a}$ & $538.85 \mathrm{~b}$ \\
\hline $\begin{array}{l}\text { Stuttgarter } \\
\text { Riesen }\end{array}$ & VermiFit A & $16.24 \mathrm{~cd}$ & $57.64 \mathrm{a}$ & $474.69 \mathrm{~b}$ \\
\hline & & 20.6 & 55.15 & 578.55 \\
\hline \multicolumn{5}{|c|}{2016} \\
\hline Rote Laaer & B-stimul & $26.61 \mathrm{ab}$ & $55.91 \mathrm{a}$ & $205.58 \mathrm{c}$ \\
\hline Rote Laaer & Control & $6.27 \mathrm{f}$ & $43.26 \mathrm{~b}$ & $353.63 \mathrm{~b}$ \\
\hline Rote Laaer & Ekobooster2 & $22.01 \mathrm{bc}$ & $19.75 \mathrm{c}$ & $351.73 \mathrm{~b}$ \\
\hline \multirow[t]{2}{*}{ Rote Laaer } & VermiFit A & $18.25 \mathrm{~cd}$ & $23.50 \mathrm{c}$ & $230.73 \mathrm{c}$ \\
\hline & & 18.28 & 36.60 & 285.41 \\
\hline \multicolumn{5}{|c|}{2017} \\
\hline Rote Laaer & B-stimul & $11.52 \mathrm{ef}$ & $44.39 \mathrm{~b}$ & $358.28 \mathrm{~b}$ \\
\hline Rote Laaer & Control & $18.31 \mathrm{~cd}$ & $25.47 \mathrm{c}$ & $253.21 \mathrm{c}$ \\
\hline Rote Laaer & Ekobooster2 & $15.70 \mathrm{e}$ & $43.48 \mathrm{~b}$ & $\begin{array}{c}393.58 \\
\mathrm{ab}\end{array}$ \\
\hline \multirow[t]{2}{*}{ Rote Laaer } & VermiFit A & $29.29 \mathrm{a}$ & $44.51 \mathrm{~b}$ & $452.37 \mathrm{a}$ \\
\hline & & 18.705 & 39.46 & 364.36 \\
\hline
\end{tabular}

Legend: The letter indicates the significant difference between treatments and cultivarsaccording to the Fisher's LSD test at $\mathrm{P}<0.05$. 
Riesen", according to those results (Table 1), it can be stated that in 2017 content of heavy metals was higher compared to 2016. The content of cadmium in 2016 ranged from $11.05 \mu \mathrm{g} \mathrm{kg}^{-1}$ to $19.31 \mu \mathrm{g} \mathrm{kg}^{-1}$,while in 2017 it was from $7.34 \mu \mathrm{g} \mathrm{kg}^{-1}$ to $31.95 \mu \mathrm{g} \mathrm{kg}^{-1}$. The treatment B-stimul in both years showed the lowest content of cadmium $11.05 \mu \mathrm{g} \mathrm{kg}^{-1}$ in 2016, and $7.34 \mu \mathrm{g} \mathrm{kg}^{-1}$ in 2017. The same treatment (B-stimul) also showed the lowest content of lead $\left(49.76 \mu \mathrm{g} \mathrm{kg}^{-1}\right)$ in 2017. As regards copper, in 2016 the lowest content was found at control (128.85 $\mu \mathrm{g} \mathrm{kg-1),} \mathrm{while} \mathrm{in} 2017$ it was at Vermifit A (474.69 $\mu \mathrm{g} \mathrm{kg}^{-1}$ ).

At the cultivar "Rote Laaer"in 2016 the lowest content of cadmium was found at the control $6.27 \mu \mathrm{g} \mathrm{kg}^{-1}$, content of lead at the Ekobooster 2 was $19.75 \mu \mathrm{g} \mathrm{kg}^{-1}$ and the content of copper at B-stimul $205.58 \mu \mathrm{g} \mathrm{kg}^{-1}$. There were no significant differences in copper content between treatments Verimfit $\mathrm{A}$ and B-stimul in the 2016 results. In 2017 the lowest content of cadmium was found in B-stimul (11.52 $\left.\mu \mathrm{g} \mathrm{kg}^{-1}\right)$, while control showed the lowest contents of lead (25.47 $\mu \mathrm{g} \mathrm{kg}^{-1}$ ) and copper (253.21 $\mu \mathrm{g} \mathrm{kg}^{-1}$ ). Results showed a statistical difference between treatments in heavy metal evaluation during 2016 and 2017. From the summary of those results (Table 1), it can be concluded that in both cultivars content of heavy metals was higher in 2017. The higher sunshine duration in 2017 showed the influence on the higher content of heavy metals regardless of the treatments. According to Commission Regulation (EC) No. 1881/2006, maximum levels for Cd and $\mathrm{Pb}$ contaminants in onion were as follows: for $\mathrm{Cd}$ $0.05 \mathrm{mg} \mathrm{kg}^{-1} \mathrm{FW}$ and $\mathrm{Pb} 0.1 \mathrm{mg} \mathrm{kg}^{-1} \mathrm{FW}$ [32]. In this research content of those metals was in line with European law. According to EU standards, the permissible level for $\mathrm{Cu}$ is $20 \mathrm{mg} \mathrm{kg}^{-1}$ [33]. In general, the levels of all the metals studied were lower than those recommended by EU standards. Brhane and Shiferaw [35]also reported the highest content of $\mathrm{Cu}$ in onion bulbs from $0.879-3.254 \mathrm{mg} \mathrm{kg}^{-1}$. The concentrations of $\mathrm{Cu}$ in onion found in this study were lower than with the values reported by Dilek D. [36] (53.83 $\left.\mathrm{mg} \mathrm{kg}^{-1}\right)$. Daily intake recommendation of $\mathrm{Cu}$ is $1.5-3.0 \mathrm{mg}$ for an adult person [34]. Therefore, the onion bulbs in the study area in both cultivars are safe and can be used as a source of $\mathrm{Cu}$.

\section{Conclusion}

The present study revealed the positive influence of organic fertilizers on vitamin $\mathrm{C}$, antioxidants and carotenoids. In the cultivar "Rote Laaer" in 2016,control showed the highest content of vitamin $\mathrm{C}$ and antioxidants. The treatment Ekobooster 2 reached positive influence on content of carotenoids in both yearsin the cultivar "Rote Laaer". The treatment B-stimul showed the highest content of vitamin C and carotenoids in 2016 in the cultivar "Stuttgarter Riesen", as well as content of vitamin C and antioxidants in 2017. Also, in 2017 treatment B-stimul showed the lowest content of $\mathrm{Cd}$ and $\mathrm{Pb}$ in the cultivar "Stuttgarter Riesen" and content of Cd in the cultivar "Rote Laaer". The values of heavy metals in this study are within the range reported in the literature. The effects of climatic conditions in 2017 showed the higher content of determined parameters in both cultivars compared to 2016. It can be concluded that the weather course in 2017, which was a year with higher mean temperature, showed the influence on the higher content on vitamin $\mathrm{C}$, carotenoids, antioxidants and heavy metals regardless of the fertilizers. The results of this study, therefore, encourage farmers to use organic fertilizer in growing good quality onions.

\section{Acknowledgements}

Current research work was supported by project No. QJ1510088 of the National Agency of Agricultural Research, Ministry of Agriculture, Czech Republic. Experiments were done on infrastructure supported by the project CZ.02.1.01/0.0/0.0/16_017/0002334 Research Infrastructure for Young Scientists, co-financed from Operational Programme Research, Development and Education.

\section{Conflict of Interest}

The authors declare no conflict of interest.

\section{References}

1. BINDU B., PODIKUNJU B. Performance evaluation of onion (Allium cepa L. var. cepa) Varieties for Their Suitability in Kollam District. International Journal of Research Studies in Agricultural Sciences (IJRSAS). 1 (1), $18,2015$.

2. CHENG A., CHEN X., JIN Q., WANG W., SHI J., LIU Y. Comparison of phenolic content and antioxidant capacity of red and yellow onions. Czech Journal of Food Sciences. 31 (5), 501, 2013.

3. KANDOLIYA U.K., BODAR N.P., BAJANIYA V.K., BHADJA N.V. GOLAKIYAB. A. Determination of nutritional value and antioxidant from bulbs of different onion (Allium cepa) variety: International Joirnal of Current Microbiology and Applied Sciences. 4 (1), 635, 2015.

4. ISLAM M., ISLAM S., AKTER A., RAHMAN M., NANDWANI D. Effect of organic and inorganic fertilizers on soil properties and the growth, yield and quality of tomato in Mymensingh, Bangladesh. Agriculture. 7 (3), 18, 2017.

5. GADELRABH.M., ELAMIN S.M. Effect of different organic fertilizers on growth, yield and total soluble solid of the onion (Allium cepa L.) variety Baftaim-s. Journal of Agricultural and Veterinary Science. 14 (1), 61, 2013.

6. VOSÁTKA M., LÁTR A., ALBRECHTOVA J. Bioadditives for vegetables growth optimization in protected cultivation. Acta Horticulturae. 1107 (1107), 149, 2015. 
7. FAWZY Z.F., SHEDEED S.I., HASSAN N.M.K. A Review of organic agricultural of some vegetables crops. American Journal of Food Science and Health. 2 (3), 25, 2016.

8. ISLAM M.A., BOYCE A.N., RAHMAN M.M., AZIRUN M S., ASHRAFM. A. Effects of organic fertilizers on the growth and yield of bush bean, winged bean and yard long bean. Brazilian Archives of Biology and Technology. 59 (Specialissue), 1. 2016.

9. DEVENDRA K.K., MAHENDRA K.L., GAURAV S.PEffect of Azotobacter on growth and yield of onion (Allium cepa L.). Journal of Pharmacognosy and Phytochemistry. 7 (1), 1171, 2018.

10. OLLE M.. WILLIAMS I.H. The Effect of organic fertilizers on the chemical quality of onions. Acta Horticulturae. 1054, 319, 2014.

11. HIDANGMAYUM A., SHARMA R. Effect of different concentration of commercial seaweed liquid extract of Ascophylum nodosum on germination of onion (Allium cepa L.). Journal of Pharmacognosy and Phytochemistry. 6 (4), 658, 2017.

12. FEIYUE R., KIM R., JOSEPH P. K., GAFFNEY M., HOSSAIN M., RAI D.K. Higher antioxidant activity, total flavonols, and specific quercetin glucosides in two different onion (Allium cepa L.) Varieties grown under organic production: Results from a 6-Year field study. Journal of Agricultural and Food Chemistry. 65 (25), 5122, 2017.

13. AKAN J.C. Determinations of some heavy metals in vegetable samples from Biu Local Government Area, Borno State, North Eastern Nigeria. International Journal of Environmental Monitoring and Analysis, 1 (2), 40, 2013.

14. MAKSIMOVIĆ I., PUTNIK-DELIĆ M., ILIN Ž., MIROSAVLJEVIĆ M. Essential $(\mathrm{Cu}$ and $\mathrm{Zn})$ and trace $(\mathrm{Pb}$ and $\mathrm{Cd})$ heavy metal loads in onion and potato. Агрознање, 13 (1), 113, 2012

15. ARYA S., MAHAJAN M., JAIN P. Nonspectrophotometric methods for the determination of Vitamin C. Analytica Chimica Acta, 417 (1), 1, 2000.

16. BRAND-WILLIAMS W., CUVELIER M.E., BERSET C. Use of a free radical method to evaluate antioxidant activity. LWT - Food Science and Technology. 28 (1), 25, 1995.

17. GALLIE D.R. Ascorbic Acid: A Multifunctional molecule supporting plant growth and development. Scientifica 2013.

18. WHO. Vitamin and mineral requirements in human nutrition (Second edi.). China. 2004.

19. GHANTI S., SHARANGI A.B. Effect of bio-fertilizers on growth, yield and quality of onion cv. sukhsagar. Journal of Crop and Weed. 5 (1), 120, 2009.

20. MANNA D., GHOSAL A., ADHIKARY R., MAITY T. $\mathrm{K}$. Influence of bio-fertilizers on growth, yield and quality of onion (Allium cepa L.) cv. Sukhsagar. Environment and Ecology. 32, 728. 2014.

21. ČOLO J., HAJNAL-JAFARI T.I., DURIĆ S., STAMENOV D., HAMIDOVIĆ S. Plant growth promotion rhizobacteria in onion production. Polish Journal of Microbiology. 63 (1), 83, 2014.

22. DILPREET T., KULBIR S., VARINDER S., JAGDISH S. Growth, yield and quality of onion as influenced by integrated nutrient management. International Journal of Agriculture Sciences. 8 (51), 2295, 2016.

23. SØLTOFT M., BYSTED A., MADSEN K. H., MARK A. B., BÜGEL S G., NIELSEN J., KNUTHSEN P. Effects of organic and conventional growth systems on the content of carotenoids in carrot roots, and on intake and plasma status of carotenoids in humans. Journal of the Science of Food and Agriculture. 91 (4), 767, 2011.

24. ITAJNER D., MILIC N., CANADANOVIC-BRUNET J., KAPOR A., ITAJNER M., POPOVIC B.M. Exploring Allium species as a source of potential medicinal agents. Phytotherapy Research. 20 (7), 581, 2006.

25. MELO E.A., GALVAO V.L.A., MACIEL L.M.I., CAETANO A.C.S., LEALF L.L. Polyphenol, ascorbic acid and total carotenoid contents in common fruits and vegetables. Brazilian Journal of Food Technology. 9 (2), 89, 2006.

26. ROHINI N., PARAMAGURU P. Seasons' Influence on bulb, seed yield and quality of aggregatum onion, Allium cepa var aggregatum. International Journal of Farm Sciences. 6 (1), 174, 2016.

27. MANGANARIS G.A., VICENTE A.R., SOZZI G.O., CRISOSTO H.C. Nutritional quality of fruits and vegetables. Postharvest Handling, A Systems Approach. Second Edition:, Edited by Wojciech J. Florkowski, Robert L. Shewfelt, Bernhard Brueckner and Stanley E. Prussia.Copyright $(2009$ published by Elsevier-Academic Press.2009.

28. ZHANG E., DUAN Y. Effects of long-term nitrogen and organic fertilization on antioxidants content of tomato fruits. Journal of Horticulture. 3 (1), 8, 2016.

29. SHEDEED S.I., BASH, D.M.A. Effectiveness of biofertilizers with organic matter on the growth, yield and nutrient content of onion (Allium cepa L.) plants. European International Journal of Science and Technology. 3 (9), $115,2014$.

30. LU X., WANG J., AL-QADIRI H.M., ROSS C.F., POWERS J.R., TANG J., RASCO B.A. Determination of total phenolic content and antioxidant capacity of onion (Allium cepa) and shallot (Allium oschaninii) using infrared spectroscopy. Food Chemistry. 129 (2), 637, 2011.

31. SIRAG N., TAJELDIN I.M., ABUBAKR M., MUDATHIR A. Determination of antioxidant activity of some varieties of onion (Allium cepa L.) grown in Sudan. Gezira Journal of Health Sciences. 11 (2), 1, 2015.

32. KUČOVÁ L., KOPTA T., SĘKARA A., POKLUDA R. Controlling nitrate and heavy metals content in leeks (Allium porrum L.) using arbuscular mycorrhizal fungi inoculation. Polish Journal of Environmental Studies. 27 (1), 137, 2018.

33. TAGHIPOUR H., MOSAFERI M. Heavy metals in the vegetables collected from production sites. Health Promotion Perspectives. 3 (2), 185, 2013.

34. RETA B.K., BHAGWAN S.C. Concentration levels of major and trace metals in onion (Allium cepa L.) and irrigation water around Meki town and lake Ziway, Ethiopia. Chemical Society of Ethiopia. 26 (1), 27, 2012.

35. BRHANE G., SHIFERAW T. Assessment of levels of lead, cadmium, copper and zinc contamination in selected edible vegetables. International Journal of Innovation and Applied Studies. 7 (1), 78, 2014.

36. DILEK DEMIREZEN A.A. Heavy metal levels in vegetables in Turkey are within safe limits for $\mathrm{Cu}, \mathrm{Zn}, \mathrm{Ni}$ and exceeded for $\mathrm{Cd}$ and $\mathrm{Pb}$. J. of Food Quality, 29 (3), 252, 2006.

37. USDA. Food composition databasesRetrieved fromhttps:// ndb.nal.usda.gov/ndb/nutrients/report?nutrient $1=401 \&$ nutr ient $2=205 \&$ nutrient $3=\& f g=11 \& \max =25 \&$ subset $=0 \&$ offset $=375 \&$ sor $\mathrm{t}=$ f\&totCount $=784 \&$ measureby $=2017$. 